\title{
QUANDO A LITERATURA É REAL BARTHES X COMPAGNON (COM UM APARTE DE XAVIER)
}

\author{
Saulo Lemos é professor da Universidade Estadual do Ceará e doutorando em Literatura Comparada pela Universidade Federal do \\ Ceará. \\ E-mail: $\underline{\text { saulo_lemos@yahoo.com }}$
}

Resumo

Este artigo confronta o ensaio "O efeito de real", de Roland Barthes, e Antoine Compagnon, em $O$ demônio da teoria, com relação ao tema realidade $\mathrm{X}$ literatura, incluindo a novela $O$ mez da grippe, de Valêncio Xavier.

\begin{abstract}
This paper confronts Roland Barthes' essay 'The reality effect' and Antoine Compagnon's Literature, theory and common sense, concerning to the relation between literature and reality, featuring Valêncio Xavier's $O$ mez da grippe
\end{abstract}

\section{1) Introdução}

A crítica literária, como qualquer criação simbólica, é atividade sujeita às transformações históricas. Ela pode assumir nova feição, ou novas feições, a cada período, em cada lugar. A diversidade dos métodos críticos propicia algo que parece transcender o embate polêmico entre eles: a divergência como indicação dialética da complexidade da cultura. É nesse cenário que surge uma hipótese: o choque cultural, inclusive quando tácito ou latente, gera uma compreensão da materialidade sígnica humana que se posta além das palavras de ordem de cada oponente. Quando o outro me contesta, ele pode estar me revelando alguma verdade que eu não havia previsto. Enxergamos essa ocorrência em contextos intelectuais específicos, como no quadro dos debates acadêmicos europeus, por exemplo. Note-se que o valor positivo do confronto com a alteridade também vale para o ambiente acadêmico brasileiro.

Como delimitação do fenômeno descrito acima, instigaremos uma discussão envolvendo o francês Roland Barthes (1915-1980) e o belga Antoine Compagnon (1950). O primeiro, um dos nomes mais evidentes da crítica literária e dos estudos de linguagem no século XX, escreve em 1968 um ensaio intitulado "O efeito de real", que bem pode sintetizar algumas de suas formulações teóricas mais importantes. O segundo, autor de obras célebres como A terceira república das letras (1983) e Os cinco paradoxos da modernidade (1989), afirma-se como um teórico e um crítico dos mais argutos e bem situados da geração recente. Em O demônio da teoria, de 1998, ele discute e confronta diretamente certas afirmações de Barthes em $O$ efeito de real e em 
outros momentos de sua obra.

Vivendo em épocas e contextos distintos, ambos infelizmente não puderam se reunir para uma troca de ideias que seria bastante enriquecedora para a crítica literária mundial. Tentamos, na ausência disso, atuar como mediadores, ou quem sabe intérpretes, de algumas de suas principais formulações críticas na tentativa de ativá-las em diálogo e discussão. Dos dois, serão utilizados para o debate simbólico alguns textos referidos, em que observamos uma semente de polêmica: o ensaio "O efeito de real", de Barthes (2004), e o capítulo "O mundo", de O demônio da teoria (Compagnon, 2006). A disparidade quanto ao direcionamento teórico empregado nas duas obras é exatamente o ponto de partida para esta tentativa de "mediação", cujos resultados esperamos serem minimamente válidos. Partiremos das considerações de Barthes, que ecoam toda uma tradição da crítica literária no século XX, para confrontá-las com a avaliação que delas executa Compagnon. Faremos, portanto, crítica de textos teóricos, o que envolve indiretamente a crítica da criação literária, que surgirá por meio de uma obra que funcionará como terceiro termo da discussão: a novela brasileira $O$ mez da grippe, do curitibano Valêncio Xavier. A forma verboimagética dessa obra a torna bastante oportuna às questões aqui desenvolvidas.

Este trabalho trata da delimitação específica da conceituação de Barthes para a literatura. Se as respostas fornecidas por orientações metodológicas de outros autores não tomam o centro da discussão, isso não quer dizer que sejam desconsideradas $a$ priori. No foco desta pesquisa, há a necessidade metodológica de delimitação. Será proposto um recorte específico daquilo que chamamos, ou tentamos chamar, de realidade. Conferir e aferir as considerações a seguir com outros métodos críticos é tanto uma possibilidade como uma necessidade; é o que esperamos do leitor deste artigo.

\section{2) Barthes: a arte é a linguagem no lugar do real}

Iniciando a exposição, é preciso sumarizar o que disse Roland Barthes de relevante para esta discussão. Em "O efeito de real", ele comenta que muitos autores relativamente recentes, como Flaubert e Michelet, acrescentam certos elementos textuais descritivos, "notações que a análise estrutural, ocupada em extrair e sistematizar a grandes articulações da narrativa, ordinariamente e até agora, tem deixado de parte" (Barthes, 2004, p. 181); esses elementos, de aspecto referencial, seriam "pormenores 'supérfluos' (com relação à estrutura)" (Barthes, 2004, p. 181). Barthes procura caracterizar aqueles elementos como índices "de caráter ou de atmosfera", para que possam "finalmente ser recuperados pela estrutura" (Barthes, 2004, p. 182). 
Sendo atribuído à fase pós-estruturalista do autor francês, o ensaio chama a atenção por visar a encontrar uma motivação funcional para aspectos textuais não enquadrados na análise estruturalista tradicional. Esta teve seus momentos mais importantes ao estudar aquilo que grosseiramente aqui se denomina narrativa tradicional. É o caso da Morfologia do conto maravilhoso (1928), de Vladimir Propp, da Antropologia estrutural (1959) de Claude Lévi-Strauss (voltada para narrativas míticas de estrutura relativamente padronizada) ou mesmo das Mitologias (1957) estudadas por Barthes. Em $O$ efeito de real, percebemos que as características da dicção moderna não a integram totalmente ao método estrutural.

No ensaio, são descritas duas modalidades distintas da estrutura narrativa, situadas em eras específicas e dotadas de caracterização particular: 1) materializada em certa modalidade de realismo desde a Poética aristotélica até aproximadamente o século XVIII, caracterizável como "preditiva" (Barthes, 2004, p. 183), pré-estabelecida pelas funções narrativas, rigorosamente calcada na noção de verossimilhança e obediente a preceitos mais ou menos clássicos de estruturação; 2) não enquadrada nos preceitos clássicos (nem na análise estrutural) da narrativa; contraponto à modalidade anterior, surgida com o realismo à Flaubert, calcada na "notação insignificante" (Barthes, 2004, p. 183), em contraponto a uma noção de organicidade do texto como condição de existência para a significância. Nessa manifestação narrativa, a verossimilhança clássica teria sido substituída pela busca moderna de um realismo que se revela e se traduz por referências textuais 1 sem coerência específica com o texto em que se inserem, a não ser por demonstrarem a casualidade imprevisível do real; elas se configurariam, portanto, como "resistência ao sentido" na perspectiva do Estruturalismo, por conta de sua não funcionalidade estrutural - porque a estrutura não se alteraria significativamente caso fossem retiradas do texto.

O insignificante que meramente designa o real, como se não fosse mediado pela linguagem, é marca do realismo pós-flaubertiano e fundamento, segundo Barthes, da ficção moderna. Esta seria então o veículo de uma "ilusão referencial”, porque nela o realismo "é apenas parcelar, errático, confinado aos "pormenores"” (2004, p. 189). Disso resultaria, finalmente, que,

suprimido da enunciação realista a título de significado de denotação, o 'real' volta a ela a título de significado de conotação; no momento mesmo em que se julga denotarem tais detalhes diretamente o real, nada mais fazem, sem o dizer, que significá-lo (2004, p. 191).

A isso Barthes denomina "efeito de real", como parte de um processo de pletora referencial e "desintegração do signo" que seria a característica maior, a "grande causa 
da modernidade" (2004, p. 191). A produção do efeito de realidade envolveria dois planos: 1) como resultado da abundância sígnica do cotidiano ocidental contemporâneo; 2) como artifício de composição ficcional característico daquele contexto. No dia a dia, o efeito de real não passa, comumente, de uma estratégia publicitária; na literatura, ele é um de seus recursos artísticos mais relevantes, na proposta "de esvaziar o signo e afastar infinitamente o seu objeto até colocar em causa, de maneira radical, a estética secular da 'representação'” (2004, p. 190). A arte literária possui aí um papel decisivo no desmascaramento do que, em outros contextos, envolve o recurso à linguagem de maneira sub-reptícia, enganatória. É dessa maneira que Barthes elege um atributo de relevo para identificar a arte moderna: o caráter autorreflexivo nas entrelinhas, a fala (escrita) artística como autocrítica da linguagem - graças ao "efeito de real".

Como decorrência daquilo que Barthes enuncia no ensaio comentado, é possível avaliar produções literárias do decorrer do século XX pela conceituação do "efeito de real". As vanguardas europeias em torno das décadas de 1900 a 1920 (do futurismo de Marinetti ao surrealismo de Breton) têm, como uma espécie de ponto comum em sua heterogeneidade, a incorporação discursiva de discursos não artísticos (até então). Esse foi, sem dúvida, um dos termos decisivos de sua noção de ruptura. $\mathrm{O}$ discurso artístico agora se alimentava de elementos anteriormente apoéticos: as gramáticas da oralidade, os desvios estilísticos e sintáticos, a linguagem "alienígena" do jornal ou da publicidade, a onomatopeia urbana2. Todos esses traços promovem um apelo referencial evidente ao contexto da Europa pós-belle époque; todos simulam aqueles tempos 3 ; produzem, portanto um efeito de real4.

A mesma consideração vale com respeito às técnicas do monólogo interior, do fluxo da consciência e, modo geral, do caráter fragmentário de muito da ficção do período (Joyce, Woolf, Proust etc.). Essas técnicas manifestam em relação à arte anterior uma feição antirrealista, mas se compõem de artifícios alusivos a dimensões da experiência humana inéditos, até então, em literatura. É assim que a presença desses artifícios poderia ser compreendida como uma ampliação do realismo em literatura, com a absorção de instâncias mais complexas do real. Essa absorção ocorreria, evidentemente, apenas em sentido metafórico; como resultado de um efeito, uma simulação, uma realização de linguagem que, no entanto, acompanha as revoluções orbitais do olhar humano.

\section{3) Compagnon: em busca da referência perdida}

"O efeito de real" é apontado por Antoine Compagnon como um dos principais argumentos em defesa de uma tese: "o referente não tem realidade, ele é produzido pela 
linguagem" (2001, p. 118); ou seja, de modo mais sucinto, trata-se da afirmação, tornada clichê, de que a literatura fala somente da própria literatura (cf. Compagnon, 2001, p. 99). Vários momentos da obra de Barthes são apontados como eco a essas assertivas. A negação da referência ao "mundo real" pela literatura, de fato tão discutida ao longo do século XX, distancia a teoria de sua recepção pelo grande público. Como diz o teórico belga, a referência é um desafio porque se postula na forma de questão tabu, "renascida das cinzas tão logo a teoria foi retirada" (2001, p. 98). No capítulo "O mundo" (2001, p. 97-138), está localizada a discussão, que a certa altura enuncia "duas teses extremas sobre as relações entre literatura e sociedade":

segundo a tradição aristotélica, humanista, clássica, realista, naturalista e mesmo marxista, a literatura tem por finalidade representar a realidade, e ela o faz com certa conveniência; segundo a tradição moderna e a teoria literária, a referência é uma ilusão, e a literatura não fala de outra coisa senão da literatura (2001, p.114).

Para Compagnon5, ambas as atitudes teriam feitio extremo, o que as levou a se tornarem "dois clichês adversários" (2001, p. 99). A ressalva às correntes teóricas referencialistas é nomeada na ordem de uma "inocência relativa à mimèsis" (2001, p.107), identificada segundo ele em Georg Lukács e devida certamente ao fato de este não situar a linguagem no centro de sua crítica; o foco da discussão de Compagnon se volta cuidadosamente à finalidade de refutar a outra tese, a antirreferencial, cujos termos são apresentados a seguir: "a referência seria uma ilusão que impede a compreensão da literatura como tal. $\mathrm{O}$ auge dessa doutrina foi atingido com o dogma da autorreferencialidade do texto literário, isto é, com a ideia de que 'o poema fala do poema’ e ponto final” (2001, p. 97). A postulação acima, cuja radicalidade conceitual e mesmo política é peculiar a determinado momento histórico, seria o respaldo decorrente de certo eventos de passagem da literatura desde o final do século XIX e pelo decorrer do século XX. Nesse intervalo, registra-se um deslocamento de modos de compreensão da obra literária, na medida em que a transparência e a adequação do texto clássico é gradualmente abandonada, e a impossibilidade de dizer o real, peculiar à dicção romântica, alastra-se no contexto de uma urbanização, via segunda revolução industrial, cada vez mais atordoadora; nessa senda é relevada uma

autonomia reivindicada para as obras literárias pelas principais doutrinas do século XX, a partir de Mallarmé, ou a "clausura do texto", tanto para os formalistas russos quanto para o New criticism americano no entre-guerras [...]. Para excluir o conteúdo do estudo literário, a teoria segue o movimento da literatura moderna, de Valéry e Gide, que já desconfiavam do realismo [...], a André Breton, ou a Raymond Queneau e ao Oulipo [...] (2001, p.102). 
Na base da descrença moderna quanto à referencialidade da obra literária, haveria dois componentes: um recente e um remoto. $\mathrm{O}$ elemento recente seria $\mathrm{o}$ contexto do capitalismo moderno, que identificaria a noção de referência como uma maneira de disfarce do discurso burguês e suas dimensões ideológicas6. Essa descrença seria herança do experimentalismo das vanguardas europeias; geradoras de uma espécie peculiar de realismo (como dito no tópico anterior), as vanguardas foram habitualmente lidas em seu tempo conforme um papel de combate contra o realismo literário tradicional. O componente remoto da argumentação antirreferencial veio de uma interpretação específica do conceito aristotélico de mimèsis. Esta, para o autor grego, resultaria de um sentido natural (provindo do eikos, o possível ou verossímil), concernente por natureza às ações humanas; subjacente à mimèsis predominaria o muthos, a formulação de enredo ou história a ser narrada, "mimèsis não do homem, mas da ação", segundo o próprio Aristóteles (1450a, 16, apud Compagnon, 2006, p. 104). O foco na abordagem estrutural do muthos da Poética levou à leitura moderna de que

essa representação da história não é analisada por ele como imitação da realidade, mas como produção de um artefato poético. Em outras palavras, a Poética não acentua nunca o objeto imitado ou representado, mas o objeto imitador ou representante (2001, p. 104).

Desse modo, a ênfase do olhar estruturalista sobre a mimèsis não recairia sobre a literatura em sua função descritiva, mas narrativa; em consonância com a crítica do vingtième siècle, a percepção de Aristóteles apontava para a poièsis como sèmiosis, e não como mimèsis; autotelismo da forma, e não sua transcendência. Compagnon não recusa esse argumento, mas avalia que ele serve ao desenvolvimento de uma tendência reducionista da teoria, no que tange a sua apropriação do real; seria algo como uma mutilação conceitual, uma restrição de âmbitos:

O importante não é que essa interpretação seja mais verdadeira ou mais falsa que a leitura tradicional, fazendo a mimèsis suportar as relações entre a literatura e a realidade - toda época reinterpreta e retraduz os textos fundamentais à sua maneira: compete aos filólogos determinar, decidir se há contra-senso; o importante é que, ao contrariar a concepção habitual de mimèsis, a realidade foi abolida da teoria: [...] deslizou-se da imitação à representação, ao realismo como efeito formal (2001, p. 105).

De acordo com o trecho citado, houve um deslocamento de 180 graus na crítica literária moderna: do eikos, associado a um olhar naturalista, à doxa, à opinião, ou à cultura e à ideologia como referências da mimèsis. A recusa ou suspeita contra esta, 
conclui o "demônio da teoria", fundamentou a não aceitação de qualquer tentativa de considerar criações discursivas (culturais, ideológicas), como se fossem naturais. Mas isso levaria a outra naturalização: a de que a mimèsis seria por natureza, ideológica, em um sentido pejorativo, e, portanto sempre falsa, sempre ilusória. Essa desconfiança absoluta é recusada por Compagnon. "A crise da mimèsis [...] é uma crise do humanismo literário, e, ao final do século XX, a inocência não nos é mais permitida" (2001, p. 107), lamenta ele. O "efeito de real" seria nesse contexto o limite extremo da proposta crítica que esvazia o conteúdo do realismo como estilo de arte; seria portanto um autêntico cul-de-sac.

Mesmo conceitos como intertextualidade e congêneres (com exceção do dialogismo de Bakhtin) de um modo geral enfatizaram a negação da referencialidade que se tornou recorrente na teoria francesa. Frente a essa tendência da crítica no século XX, surge um questionamento: mesmo se a referencialidade for uma ilusão, isso não resultaria de qualquer modo em uma referência à realidade? Uma referência pela negação da referência, dialeticamente? É o que pergunta Compagnon com base em The order of mimesis, de Christopher Prendergast (1986). "Quem diz ilusão, diz realidade, em nome da qual se denuncia essa ilusão. Nesse jogo, gira-se no mesmo lugar" (2001, p. 118). É fato que a linguagem funciona como verdadeira armadilha, o que deve ser considerado com cautela para ser retomado adiante neste artigo.

Diante do referido campo de forças entre pólos opostos, Compagnon volta à Poética de Aristóteles, passando pela leitura que dela fizeram Northrop Frye, Paul Ricoeur e Terence Cave, no encalço de uma "terceira leitura", não maniqueísta, da noção de mimèsis. Primeiramente, da apreciação aristotélica para a mimèsis é mencionado o detalhe de que mimeisthai (imitar ou representar) faz parte do aprendizado humano geral7, sendo portanto uma forma de "conhecimento, e não cópia ou réplica idênticas: designa um conhecimento próprio ao homem, a maneira pela qual ele constrói, habita o mundo" (2001, p. 127). Para os três teóricos citados, Compagnon tece o seguinte trajeto: 1) Northrop Frye, em Anatomia da crítica (1969), prioriza em sua leitura da poética a ordem semântica da mimèsis, e não a sintática, como preferiu o estruturalismo; assim, o ponto alto da construção mimética estaria na função de anagnôrisis, o reconhecimento que o herói trágico faz de seu destino, e que Frye associa ao reconhecimento que o leitor faz dos rumos que o texto lido está seguindo; 2) Paul Ricoeur, em Tempo e narrativa (1983-1985), afirma a mimèsis como operação, realização, como criação de fatos, criação da realidade, que vai da representação do real à percepção deste, pelo leitor, na obra; 3) na obra Recognitions: a study in poetics (1988), de Terence Cave, Compagnon enxerga uma especificação mais eficiente dos modelos de compreensão da poética de Aristóteles por Fry e Ricoeur: a mimèsis, com 
apoio em observações do historiador Carlo Ginzburg, torna o leitor

um detetive, um caçador à procura de indícios que lhe permitirão dar um sentido à história. O signo de reconhecimento na ficção remete ao mesmo modo de conhecimento que a pegada, o indício, a marca, a assinatura e todos os demais signos que permitem identificar um indivíduo ou reconstruir um acontecimento. (2001, p. 132).

O caçador, tal como o adivinho que visualiza o futuro (outro modelo utilizado por Cave), e como o autor e o leitor, usa indícios para compor uma história resultante em mimèsis, em narrativa, em conhecimento. Compagnon, então, opina que a mimèsis não é necessariamente uma cópia, mas um reconhecimento da realidade realizado à medida que o discurso textual da escrita e da leitura se constrói. A mimèsis, nessa formulação, está isenta dos "fatores extraliterários (existenciais, éticos)" incluídos por Frye e Ricoeur e "constitui uma forma especial de conhecimento do mundo humano, segundo uma análise da narrativa muito diferente da sintaxe que os adversários da mimèsis procuravam elaborar, e que inclui o tempo do reconhecimento" (2001, p.133); assim Compagnon reabilita a referencialidade na compreensão da literatura. Essa leitura visa a recuperar, ou a erguer, uma abordagem semântica para a obra literária. Entretanto, a semântica também é gerada e compreendida como parte da forma, ou seja, também é vista a partir da linguagem8, tal como a sintaxe.

\section{4) A realidade da linguagem (literária, inclusive)}

O debate entre Barthes e Compagnon, como proposto acima, alude a concepções distintas sobre o tópico da realidade; e alude, embora nem sempre de modo direto, à maneira (ou às maneiras) como a literatura se relaciona com o mundo exterior a ela. Apresentados os argumentos de cada parte, a sequência óbvia do processo é aferir uns com os outros e checar que relações eles estabelecem entre si. Desse confronto pode surgir uma reafirmação do conceito de literatura mais próxima a um dos dois ou que sintetize ambas as propostas. Pode ser também que a indeterminação conceitual persista. É preciso, em todo caso, avaliar os termos do embate, que talvez seja validado caso se consiga responder uma questão crucial à discussão: o que é realidade?

Esse conceito tem se ligado a acepções bastante díspares desde a Antiguidade. Para Platão e todos os filósofos idealistas que lhe prestam algum grau de tributo, a realidade é um espaço fora de nosso alcance físico, que intuímos, mas desconhecemos: um mundo além, a destinação após a transcendência da matéria. Para a filosofia materialista em geral, beneficiada, dentre outros, pelos estandartes da física newtoniana, a realidade é palpável, fruto de um cogito sobre o hic et nunc. Sua célula básica é a 
captação dialética dos fatos. Para a fenomenologia, herdeira do idealismo romântico, o real não apenas está na materialidade física, mas também, e principalmente, na experiência sensorial e imaginativa. A realidade hoje é potencialmente tudo isso, conforme as escolhas de cada grupo cultural. De todo modo, definir realidade continua uma tarefa difícil; a disparidade das respostas só não é maior que o vigor da pergunta. Onde o olhar alcança, há um aspecto a ser entendido, realizado. Talvez haja o consenso de que a realidade é complexa e, portanto, esquiva às definições9.

Em sua argumentação, Compagnon cita trechos de obras de Barthes para associá-los a "O efeito de real". Da Introdução à análise estrutural das narrativas, obra de 1966, o belga traz em apud um trecho específico sobre o problema da referência, em que se lê:

A função da narrativa não é a de "representar", mas de constituir um espetáculo que ainda permanece muito enigmático, mas que não poderia ser da ordem mimética. [...] "o que se passa", na narrativa não é, do ponto de vista referencial (real), ao pé da letra, nada; "o que acontece", é só a linguagem inteiramente só, a aventura da linguagem [...] (2001, p. 101).

O trecho acima fundamenta a concepção de que, em Barthes, o método estruturalista despreza o real como objeto do estudioso da linguagem (e, por conseguinte, do crítico literário). A forma literária seria algo isolado da realidade, que não participa dela. Isso, porque o Estruturalismo se advoga um "princípio da imanência, limitando-se o linguista ao estudo dos enunciados realizados" (Dubois et al, 1997, p.248), o que pode ser compreendido como modo de delimitação metodológica; propondo-se entender cada elemento de uma estrutura textual em relação a todos os outros que dela participam, esse método torna imperativo o ato de estabelecer laboratorialmente o âmbito exato do organismo ou do excerto orgânico a ser descrito e funcionalizado.

Barthes, amistoso ao programa estruturalista, extremiza sua adesão ao fazer afirmações como as que se leem no trecho reproduzido anteriormente ou como esta, também citada por Compagnon: "no mais realista dos romances, o referente não tem "realidade"” (2001, p. 109). O foco de abordagem sobre as manifestações da língua, literárias ou não, leva a um lance epistemológico radical: a linguagem não coincidiria com qualquer coisa denominável pela palavra "realidade". Haveria uma fronteira rígida e inevitável entre ambas, e o trabalho do semiólogo barthesiano fundaria nisso uma pressuposição. Hoje seria possível enxergar o reducionismo dessa conclusão e do ponto de partida que a originou; seria possível refutá-la: a teoria e a crítica transcorridas desde então o permitiriam. É válido, de todo modo, tentar entender por que a linguagem em 
Barthes é dissociada do real, para captarmos até que ponto tal dizer se verifica ou não.

No ensaio "Da ciência à literatura", escrito um ano antes de "O efeito de real", Barthes parte da distinção entre esses dois saberes à enumeração de suas semelhanças; dentre estas, que elas "são discursos [...], mas a linguagem que a ambas constitui, a ciência e a literatura não a assume, ou se preferirem, não a professa da mesma maneira" (2004, p. 4). E prossegue:

Para a ciência, a linguagem não passa de um instrumento, que se quer tornar tão transparente, tão neutro quanto possível, submetido à matéria científica (operações, hipóteses, resultados) que, ao que se diz, existe fora dela e a precede [...]. Para a literatura, ao contrário, pelo menos aquela que adveio do classicismo e do humanismo [e, portanto, do romantismo e seus sucessores], a linguagem já não pode ser o instrumento cômodo ou o cenário luxuoso de uma "realidade" social, passional ou poética que preexistiria a ela e que, subsidiariamente, teria a incumbência de exprimir, mediante a sua própria submissão a algumas regras de estilo; a linguagem é o ser da literatura, seu próprio mundo [...]" (2004, p. 4-5, grifos nossos).

Sendo discursos, literatura e ciência são distinguíveis, ao menos em certo momento histórico não sinalizado acima, antes pela maneira como são socialmente lidas e acionadas que por propriedades textuais imanentes. A ciência, em certos períodos, afirmou a objetividade, o caráter prévio à formulação discursiva que a materializava, como condição de credibilidade; a literatura, no correr de seus desdobramentos nos séculos recentes, é vista antes de tudo como linguagem; aliás, é como linguagem que ela constitui uma realidade específica, cujos atributos produziriam uma cisão entre ela e o que mais puder ser chamado de real. E assim Barthes direciona suas razões:

Eticamente, é tão somente pela travessia da linguagem que a literatura persegue o abalamento dos conceitos essenciais da nossa cultura em cuja primeira linha, o de real. Politicamente, é ao professar e ao ilustrar que nenhuma linguagem é inocente, é ao praticar o que poderia se chamar de "linguagem integral" que a literatura é revolucionária. Assim, a literatura se vê hoje sozinha a carregar a responsabilidade inteira da linguagem; pois, se a ciência, indubitavelmente, precisa da linguagem, ela não está, como a literatura, $n a$ linguagem (2004, p. 5-6, grifo do autor).

Barthes, nas passagens acima, mostra aceitar a linguagem como uma realidade; é nela, ou por meio dela, que se fruem as experiências da vida humana, inclusive no aspecto político. Se a realidade é complexa, e captá-la de maneira totalizadora pode ser algo mais difícil que aparenta ser, haveria ao menos um ponto de afluência e confluência da diversidade do real: a linguagem. Nela se pode encontrar uma delimitação material para o que quer se deseje nomear de realidade. A linguagem é uma realidade, é um mundo. Barthes a compreendia como a única realidade alcançável, e

\footnotetext{
Revista Escrita

Rua Marquês de São Vicente, 225 Gávea/RJ CEP 22453-900 Brasil

Ano 2012. Número 14. ISSN 1679-6888.

escrita@puc-rio.br
} 
nisso há uma clara definição de método; ante a dificuldade em apreender a paisagem ao redor, o recorte de Barthes e de muitos estudiosos é buscar o real na linguagem, ponto. $\mathrm{O}$ mencionado radicalismo do crítico francês o proibiu de enunciar a ocorrência de realidade além da linguagem. Essa é, em última síntese, a restrição que lhe faz Compagnon.

O autor de Le plasir du texte não se propôs discutir se há ou não uma realidade além da linguagem; e isso porque talvez o recorte metodológico mais propício a quem estuda linguagem (inclusive literária) envolva enfocá-la em primeiro plano. É na linguagem que se materializa e se percebe o real; é nela que este é encontrado ${ }^{10}$. Se a referência a um mundo externo à linguagem existe, provavelmente isso não produz nada mais que uma sensação de ligação com o outro e, desse modo, de uma espécie de conforto psicológico. Para o circuito das humanidades, especular sobre o mundo fora da linguagem é possível, embora talvez seja igualmente impreciso. É nisso que a crítica de Compagnon perde vigor, porque sua definição de realidade é vaga, e ele não reconhece explicitamente o real a partir da linguagem, embora esse pressuposto ecoe por todo o capítulo "O mundo", de $O$ demônio da teoria.

A crítica "formalista" chegou a considerar a ligação entre a obra e o mundo uma preocupação antiquada, mas isso pode, entretanto, passar despercebido ao leitor comum que ainda recorre à obra literária sem um olhar crítico especializado. Os professores de literatura ressaltam a forma; os alunos, principalmente se iniciantes, tendem a atentar mais para o conteúdo $^{11}$. Porém, se o modo de exposição conceitual do pósestruturalismo (ou pelo menos de Barthes) se tornou um clichê da teoria, parece que muitas questões por ele discutidas não se esgotaram. A afirmação de que "nenhuma linguagem é inocente" converge para o contexto comunicacional e artístico da modernidade tardia, com a hiperdisponibilidade da informação e seu reiterado uso mercadológico e subliminar; desse modo, aquela afirmação é bastante convincente. Aqui nesta "arena", ressalta uma oposição: sintaxe (Barthes) x semântica (Compagnon), que parece mascarar a verdadeira antítese em jogo: crença $X$ desconfiança na linguagem. A metáfora do leitor/escritor como caçador ou mago, cara a Compagnon, não permite cogitar a possibilidade de o caçador se equivocar, ou de o mago não ser mais que um taumaturgo. Compagnon situa Barthes em uma posição teórica extrema e predica, ao invés, um ponto intermediário. E por não admitir a linguagem como ponto de partida e de chegada do real, ele recai possivelmente na ingenuidade que disse querer evitar. O arco-íris descrito de modos diferentes é sempre o mesmo, mas é apenas pela linguagem que ele se realiza socialmente, que existe como percurso do eu ao outro.

Em $O$ demônio da teoria, Compagnon conceitua a teoria literária por meio de uma função que ele observa nela: "o que a caracteriza, na verdade, é justamente o 
contrário do ecletismo, é seu engajamento, sua vis polemica, assim como os impasses que a esta última a leva sem que ela se dê conta" (2001, p. 16). Contudo, o questionamento de Compagnon, em nome de um fundamento teórico questionador, inconformista e independente do senso comum, pode perigosamente se confundir com este. A teoria da desconfiança contra a linguagem, mesmo que pareça tentá-lo (e não é o caso), certamente não detém a última palavra sobre a história e a cultura. Confrontando os dois autores em estudo, lembramos a hipótese de Octavio Paz para delimitar um traço do pensamento ocidental recente: "la razón tiene la tendencia a separarse de ella misma: cada vez que se examina, se escinde; cada vez que se contempla, se descubre como otra ella misma" (1993, p. 48-49). A indagação contra Barthes pode reavivar questões adormecidas pelo tempo e pelo senso comum. Talvez porque o conflito da razão ocidental consigo mesma, exemplificado no confronto entre os dois autores principais aqui discutido, é um conflito cujo tatame é primordialmente a linguagem.

\section{5) O que uma obra literária tem a dizer}

A realidade é um simulacro a ser denunciado pelo discurso literário, ou este pode ser creditado como espaço de conhecimento e experiência vital? Uma obra literária oferece provavelmente uma resposta mais confiável que a da própria crítica. A polêmica sobre a referencialidade da literatura é oportuna para uma abordagem de $O$ mez da grippe, espécie de narrativa publicada em 1981 pelo curitibano Valêncio Xavier (19332008). Ele foi diretor e roteirista de cinema e vídeo; em literatura, produziu obras de caráter bastante experimental, mesclando imagens diversas e texto verbal em gêneros variados. Sua produção é pouquíssimo conhecida. Seus livros são em parte herdeiros de textos como alguns manifestos de Marinetti ou o poema "Manucure", de Mario SáCarneiro. Xavier, no entanto, aumenta a presença da imagem e de recursos gráficos variados em seus textos, não utilizando o parágrafo tradicional e suas marcas discursivas mais comuns.

O mez da grippe é anunciado, em suas primeiras páginas, como uma "novella". O esparso texto de Xavier convive com imagens que reproduzem notícias de jornal, anúncios publicitários, fotografias, desenhos tipográficos e comunicados governamentais à população curitibana, todos datados de outubro, novembro e dezembro de 1918. Nesse intervalo de tempo, a gripe espanhola se tornara uma pandemia global e a I Grande Guerra chegava a seus momentos finais: o aqui frente ao lá. A série de textos contíguos forma uma espécie de arquivo documental sobre fatos naquele ano; forma também uma modalidade especial de narrativa, articulada na mente do leitor. Esse aspecto a aproxima de muitas obras do século XX, cuja estrutura 
fragmentada exige uma leitura pronta a amarrar dados "soltos" e montar uma tessitura.

A "novella" de Xavier, em sua quase totalidade, não foi escrita por ele. Após sua leitura e a devida conexão de seus encaixes, percebe-se que seus personagens são, em geral coadjuvantes, incidentais; a narrativa, amparada na recorrência dos temas da gripe e da guerra, não possui enredo tradicional. A organização temporal é que não se afasta tanto da perspectiva linear: os registros são apresentados dia a dia, com indicação precisa de data e mês. O mês da gripe, aliás, é novembro. O auge da infecção. Além dos textos da época, dispostos na ortografia de então (como o título sugere), há inserções que não parecem provir de nenhuma das fontes recorrentes. Por exemplo, a sequência de pequenos trechos em que um homem percorre as ruas desertas da cidade, adentra uma casa e encontra uma bela mulher doente, o que o leva a abusar sexualmente de seu corpo. Barbaridade puramente ficcional, em um contexto de horror e exceção suscitado por uma peste de proporções bíblicas? Não há fonte que o diga, no livro. Essa sequência, entremeada pelos outros tipos textuais da obra, é toda apresentada em pequenos versos livres, cujo final é este:

Mas sempre terei diante de mim

A visão de eu abrindo a porta

A casa vasia [sic], seu corpo de loura plumagem

Sem me voltar, sem voltar

Diante de mim, a cidade vazia, silenciosa

Nestes dias da grippe

Ninguém me viu nem me verá (Xavier, 1998, p. 66)

A proposta de Xavier seria efetivamente literatura? Não é a primeira vez que obras literárias casam verbo e imagem: as edições do Quixote acompanhadas tradicionalmente das ilustrações de Gustave Doré, O Ateneu com as gravuras de seu autor, o romance Nadja, de André Breton. No caso de Xavier, o espaço da imagem é dilatado, de modo que ela pode alçar conotação pictórica e formar com a palavra uma poesia peculiar. Aqui se considera a hipótese de, sim, $O$ mez da grippe ser uma obra literária. $\mathrm{O}$ argumento de que se trata de um mero registro documental é esteticamente superado pelo caráter aberto, polissêmico, de certos pontos: como exemplo, nos recortes textuais (um trecho extraído do Commercio do Paraná: “... positivamente a vida humana não vale um caracol... - Xavier, 1998, p. 16); e, também, nos depoimentos de uma personagem chamada Dona Lúcia (verdadeiros? Fictícios?) sobre uma provável sobrevivente à "grippe" (seria a mulher estuprada? Esta interrogação também é parte da narrativa):

"Ela, a mulher, nunca mais ficou com o juízo perfeito. Passava uns tempos boa, teve até 
um filho, criança linda. De repente, dava assim como uma tristeza nela, saía a andar sozinha pelas ruas, sempre com um vidrinho de veneno nas mãos. Nunca largava do veneno, mesmo quando estava normal, alegre com o marido e o filho..."

DONA LÚCIA - 1976 (Xavier, 1998, p. 66).

A compreensão do livro requer dados externos a ele? Os registros da história da República Velha e da Europa na década de 1910 são necessários para compreendê-lo? Sim, se a expectativa é de contextualização histórica precisa. Ao leitor cauto e treinado, a leitura de $O \mathrm{mez}$ da grippe sem o recurso ao livro de história é suficiente para evocar uma realidade assolada pela doença, por uma condição civilizatória específica (a da América pós-colonial) e pela guerra europeia. A função de reconhecimento do real mediante indícios do cotidiano, preceituada por Compagnon, assim se exemplifica. A paisagem curitibana durante o "mez da grippe", todavia, é bem diferente da floresta onde o caçador busca sua presa ou o mago invoca seus sortilégios; não é tão fácil de prever ou mapear, não é óbvia, não é transparente, mas possui constituição sígnica frequentemente traiçoeira: apesar de tentativas oficiais de dizer o contrário ${ }^{12}$, a "grippe" aumentava gradualmente seu número de vítimas. E a repercussão da guerra disfarçava, mostrando, ancestrais ressentimentos da América portuguesa frente à Europa. Barthes avisou, Compagnon contestou e Xavier complicou. O excesso de ceticismo talvez diminua a visão; mas nada impede que o olhar desiludido, não ingênuo, desfrute saudavelmente da fantasia, da boa ilusão ficcional, do prazer em querer acreditar e em se dedicar à utopia.

\section{6) Considerações finais}

Para os textos estudados, o que os dois teóricos em debate realizaram se mostra em conflito. A obra literária, nesse ínterim, vem para dar razão a ambos, de certo modo. As verdades de ambos, de todo modo, são válidas em contextos determinados. Só mesmo a obra literária para totalizar a crítica; só mesmo ela, para dar sentido ao radicalismo talvez meio descontextualizado de Barthes ou à imprecisão de Compagnon em tratar de sua matéria-objeto, a linguagem. O legado de Barthes, seja dito, não pereceu; se foi mal aproveitado por seu discípulo e inquisidor, o ceticismo como método, adotado por este, revela-se uma ferramenta crítica de valor, com o perdão do trocadilho. Acima de tudo, só a história ditará a permanência ou o esgotamento desta ou daquela corrente de crítica literária.

Para o crítico que se volta retrospectivamente às elaborações teóricas contra e a favor da ligação entre a obra literária e o mundo, talvez a possibilidade de compreensão mais rica esteja em não perder de cena a maleabilidade da representação, bem como 
manter no horizonte conceitual a sua designação de forma humana de conhecimento da realidade. As imagens que produzimos falam mais de nós ou do que nos lembram? A resposta depende de uma dialética particular envolvendo desconfiança e afirmação. Provavelmente falam mais de nós. O homem formula seu conhecimento do que é real criando textos que delimitam esse real; mas em outras situações, são as representações, os textos já constituídos, que alimentam novas versões sobre o que é a realidade. A mimèsis pode ser associada aos conceitos lingüísticos de enunciado (no que possui de pictórico, representativo) e enunciação (no que possui de processo, criação, conhecimento e reconhecimento), conforme os conceituam Dubois et al (1997, p. 218219). Imagem e ato de imaginar, bom para os sentidos (físicos, textuais) treinados no hoje.

As ressalvas aqui apontadas não desabilitam totalmente a metodologia do estruturalismo, mas indicam ter sido necessário argui-la e mesmo ultrapassá-la. Se a mimèsis cria o real por meio de discursos, de textos (inclusive literários), o real é acessível, preferencial ou unicamente, pelo discurso, o que dá validade ao "efeito de real" barthesiano, alimentado por discursos anteriores (a tradição literária, valores cotidianos, a própria noção habitual de realidade etc.). $\mathrm{O}$ realismo em literatura não seria mais uma proximidade da literatura ao que lhe é exterior, mas a sensação, produzida pelo signo textual, dessa proximidade. A desconfiança estruturalista ante a linguagem foi e, em certas proporções, é ponto de vista valioso para a compreensão crítica do mundo; e, paradoxalmente, para a compreensão crítica das relações que a literatura pode estabelecer (não como ligações dadas, acabadas, mas sempre em possibilidade de modificação) com aquilo que tentamos cotidianamente qualificar como realidade. Delimita-se uma opção para a crítica, hoje: duvidar da linguagem, mas lhe permitindo, sempre que possível, um sopro vital de energia.

Notas:

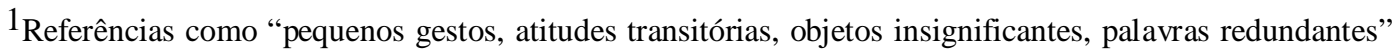
(BARTHES, 2004, p. 187).

${ }^{2}$ As marcas textuais descritas acima, além de uma contextualização de seus propósitos e seus efeitos conforme suas repercussões poéticas e políticas, podem ser conferidas em Teles (2005, p. 81-208).

3 Para os contemporâneos de então, para os historiadores de hoje, por exemplo.

${ }^{4}$ Não isenta de ironia, esta afirmação de Levinas sugere o caráter realista da experimentação artística: "Desacreditado como cânon estético, o realismo conserva todo o seu prestígio. De fato, ele não é renegado senão em nome de um realismo superior. Surrealismo é um superlativo" (1994, p. 107 tradução nossa).

${ }^{5}$ Ele não situa nesse painel esquemático a Mimèsis de Erich Auerbach, limitando-se a qualificá-la como um livro "rico" (2001, p. 132).

Revista Escrita

Rua Marquês de São Vicente, 225 Gávea/RJ CEP 22453-900 Brasil Ano 2012. Número 14. ISSN 1679-6888.

escrita@puc-rio.br 
6 Aproximadamente no mesmo período, Georg Lukács desenvolvia uma concepção inversa, de caráter positivo, do papel da referencialidade em literatura, notadamente em seu estudo The historical novel (1976), escrito em 1936-7. Privilegiando a abordagem política e a crítica social em sua definição de arte literária (conforme a orientação marxista), Lukács considerava o romance realista do século XIX menos corrompido pelos valores burgueses que as obras resultantes da experimentação estética do século XX.

7 Um trecho pertinente da Poética, capítulo IV: "Imitar é natural ao homem desde a infância - e nisso difere dos outros animais, em ser o mais capaz de imitar e de adquirir os primeiros conhecimentos por meio da imitação - e todos têm prazer em imitar" (Aristóteles, 2005, p. 21-22).

8 Segundo a proposta do linguista dinamarquês L. Hjelmslev, o conteúdo ou assunto de um texto possui uma dimensão formal, estrutural, que envolve as intenções do falante (cf. DUBOIS et al., 1997, pp. 148149, verbete "Conteúdo").

9 Como "introdução à complexidade do real”, digamos, leia-se Júnior (1994).

10 Esta afirmação, de que é pela linguagem que se toca o real, é formulada mais ou menos implicitamente nos escritos de vários autores relevantes aos estudos de linguagem no Ocidente, como é o caso de Wittgenstein (2005), Derrida (1967, 2006) e Foucault (2002), dentre muitos outros. Duas menções literais, entretanto, podem ser feitas a W. Luijpen ("Não há sentido sem palavras nem mundo sem linguagem" - apud Júnior, 1994, p. 17) e a Heidegger ("Na palavra, na linguagem, é que são primeiramente as coisas" - apud Júnior, 1994, p. 17).

11 Isso, sem mencionar a noção de que forma e conteúdo só são separáveis de maneira abstrata (Derrida, 2006).

12 Seus registros se multiplicam no livro de Xavier, o qual não inclui nenhum texto da época ou posterior desmascarando o caráter falso do discurso oficial.

\section{Referências Bibliográficas}

BARTHES, Roland. "Da ciência à literatura". In: O rumor da língua. Trad. Mario Laranjeira. 2. ed. São Paulo: Martins Fontes, 2004.

. "Efeito de real". In: O rumor da língua. Trad. Mario Laranjeira. 2 ed. São Paulo: Martins Fontes, 2004.

COMPAGNON, Antoine. "O mundo". In: O demônio da teoria: literatura e senso comum. Trad. Cleonice Paes Barreto Mourão e Consuelo Fortes Santiago. Belo Horizonte: UFMG, 2006.

DERRIDA, Jacques. L'écriture et la différence. Paris: Seuil, 1967.

. Gramatologia. Trad. Miriam Chnaiderman e Renato Janine Ribeiro. 2 ed.

São Paulo: Perspectiva, 2006 (Estudos).

DUBOIS, Jean et al. Dicionário de lingüística. Trad. Frederico Pessoa de Barros et al. $6^{a}$ ed. São Paulo: Cultrix, 1997.

FOUCAULT, Michel. As palavras e as coisas: uma arqueologia das ciências humanas. Tradução de Salma Tannus Muchail. 8. ed. São Paulo: Martins Fontes, 2001.

JÚNIOR, José-Flávio Duarte. O que é realidade. 10. ed. São Paulo: Brasiliense, 1994. LEVINAS, Emmanuel. Les imprévus de l'histoire. Paris: Fata Morgana, 1994.

LUKÁCS, George. The historical novel. Translated by Hannah and Stanley Mitchell. Middlesex: Penguin, 1976.

PAZ, Octávio. Los hijos del limo: del romanticismo a la vanguardia. Barcelona: Seix Barral, 1993.

TELES, Gilberto Mendonça. Vanguarda européia e modernismo brasileiro: apresentação e crítica dos principais poemas, manifestos, prefácios e conferências Revista Escrita

Rua Marquês de São Vicente, 225 Gávea/RJ CEP 22453-900 Brasil 
vanguardistas. 18. ed. Petrópolis: Vozes, 2005.

XAVIER, Valêncio. O mez da grippe e outros livros. São Paulo: Companhia das Letras, 2002.

WITTGENSTEIN, Ludwig. Investigações filosóficas. Trad. Marcos G. Montagnoli. 4. ed. Petrópolis: Vozes, 2005. 